\title{
The Town as Agrarian Dissipative Structure: Cash Crops in the Medieval Kingdom of Galicia
}

\author{
Andrés Teira-Brión 1,*, Xurxo Constela Doce ${ }^{2}$, Miguel Sartal Lorenzo ${ }^{3}$, Dolores Gil Agra ${ }^{4}$ and Víctor Rúa Carril ${ }^{5}$ \\ 1 School of Archaeology, University of Oxford, Oxford, UK. andres.teirabrion@arch.ox.ac.uk \\ 2 A Citania Arqueoloxía, Pontevedra, Spain. acitania@acitania.com \\ 3 ADRO Arqueolóxica, Rianxo, Spain. migasl@yahoo.es \\ 4 Independent archaeologist, Noia, Spain. lgilagra77@gmail.com \\ 5 Independent archaeologist, Vilagarcía de Arousa, Spain. victor.rua.carril@mundo-r.com \\ * Correspondence: andres.teirabrion@arch.ox.ac.uk; A.T.B.
}

\begin{abstract}
Towns emerged as dynamic economic and political centers during the Middle Ages, giving rise to the emergence of new social classes. As a result of these functions, a new relationship began to be forged with the rural world, which supplied towns with foodstuffs that satisfied new social demands. Archaeobotanical analysis (carpology) allows us to understand the flow of cash crops by tracing seeds and fruits produced in the countryside that were consumed in and redistributed from the towns. The study of waterlogged contexts from medieval archaeological sites in the Kingdom of Galicia (Santiago de Compostela, Padrón, and Pontevedra) has provided a set of species that played a crucial role in the economy of the urban dwellers and that possibly were related to differential access or food preferences. Evidence for fruits (grapes, chestnuts, figs, apples, and cherries, among others), garden crops (melon), and cereals (foxtail millet, rye, naked wheat, and oat) has been documented. Broomcorn millet is particularly abundant, demonstrating that it was important for subsistence. Some of the species found (medlar, turnip/grelo, and spinach) are novel in the archaeobotanical literature of the medieval period in the Iberian Peninsula.
\end{abstract}

Keywords: urban; rural; millet; garden; orchard; Iberian Peninsula; High/Late Middle Ages

\section{Introduction}

Understanding towns as dissipative structures, whose function requires social links with places outside the town walls, can help us to understand patterns of exchange and dependency with, among other spheres, agricultural production. In the words of I. Prigogine "...the town lives by exchanging raw materials or energy with the surrounding countryside. It is the function that creates the structure. But the function, the flow of matter and energy, is evidently a non-equilibrium situation" [1]. As a dissipative system, towns need to direct the production of crops to ensure their subsistence, and to control the distribution of goods for their economic development. They do this by weaving networks of social and labor dependency. In this way, the flow of food from the countryside embodies the relationships established between the urban and the rural environment. Crops can be understood both as elements of an agricultural landscape triggered by these relationships over time, and as the materialization of the social determinants and preferences of the different inhabitants of the town, from the most privileged to the impoverished.

At the end of the Middle Ages, the economic climate favored the reinvigoration of the towns in Galicia, which began to aggregate mercantile functions. The basis of this growth was the movement of goods and the emergence of a commercial and artisan bourgeoisie [2], alongside a renewal of the manorial power structure. The ruling class (including the monarchy) had a particular interest in the promotion of towns through the granting of privileged statuses, such as charters [3,4]. However, it was the town councils that best epitomized the change in the relationship between powers, as they acted as institutions that decentralized feudal power by bringing together competence in justice, administration, supply, and town planning [5, 6]. 
The urban activity generated a migratory process from the countryside that led to the concentration of the population. As a result, the walled perimeters were extended to accommodate the new neighborhoods outside the walls and suburbs emerged under the protection of their entrance gates and access roads. However, despite this growth, Galician cities were generally small in size compared with other European examples [7]. The largest settlements (A Coruña, Santiago de Compostela, and Pontevedra) comprised an area of between 37 and 20 ha inside their walled enclosures. Other cases were secondary settlements of regional importance; for example, towns such as Noia, Vigo, and Padrón would not have been larger than 5 ha. Possibly, their urban status was based more on the accumulation of functions, which made them cohesive as centers of political and economic power, than on their population size with respect to that of a very densely inhabited rural area. Thus, in the fifteenth century, Pontevedra would have housed a population of approximately 5,000 [8] or 6,500 thousand people [9] and Santiago de Compostela between 4,000-5,000 [10] to 8,000 [9] inhabitants. This denotes the existence of an urban phenomenon with unique characteristics within Europe, which, rather than originating from a development of a middle-class, was an important part of the power game over the space and its people [4].

Rural areas, for their part, were also capable of generating their own social ecosystems. As R. Schreg points out [11], the medieval village comprised the totality of the settlements, the inhabitants, their surrounding landscape, and their mutual activities as a dynamic, organic whole, but the village's function itself depended on its main bio-productive systems (agricultural land, pastures, forests, and wetlands) and was conditioned by various socio-economic factors (land tenure, social structures, reproduction, and power relations, among others). However, this rural ecosystem did not function in isolation; many of its agricultural decisions were made based on the economic interest of the ruling class (based on feudal class inequalities). Land and its products were conceived of as goods by the nobility, whose wealth accumulation was the basis of their socio-economic power.

As a research methodology, archaeobotany plays a crucial role to provide a variety of information on human diet, trade networks, socio-economic differentiation, and agricultural developments in medieval towns [12]. To understand how the relationships of dependency were woven between the urban and rural spheres, this work focuses on the study of the agricultural products that arrived at three towns of the medieval Kingdom of Galicia (Santiago de Compostela, Padrón, and Pontevedra) through study of the seed and fruit remains recovered from several archaeological refuse disposal contexts (Figure 1). Tracing the cash crops has allowed us, first, to understand the carpological assemblages studied within the framework of plant consumption and redistribution flux and, second, to know which plant-based products were mainly demanded by the urban dwellers.

\subsection{Historical Background}

The Kingdom of Galicia was a territory whose geographical and political conception was variable during the Middle Ages $[13,14]$. Although the kingdom had brief periods of political sovereignty, more often it was integrated within peninsular monarchies whose centers of power were located farther east. As an independent state, it arose from the arrival, at the end of Antiquity (409-585 CE), of the Suebi people in the Roman province of Gallaecia, later annexed by the Visigoth kingdom of Toledo (585 CE). Despite the military incursions of the Umayyad Caliphate into the Iberian Peninsula from 711 onwards, the northwestern region remained largely outside their political control, gradually consolidating its autonomy thanks to the royal court located in Oviedo [15]. Under the patronage of the Asturian dynasty, the town of Santiago de Compostela became the main place of Christian pilgrimage in western Europe.

In the 10th-12th centuries, there were brief periods of political independence in Galicia in the context of the disputes between the heirs to the Crown of León. But, from the 12 th century onwards, certain changes in the geopolitical scenario led to a gradual decline in the heft of Galicia within western Iberia. In 1126, the title of King of Galicia became part 
of the Crown of León definitively; the separation of the County of Portugal (1095) led to the autonomy of the southernmost region and the subsequent founding of the Kingdom of Portugal in 1139 [16]; and, finally, the integration of the Crown of León into the Kingdom of Castile in 1230 meant a further distancing of the northwesternmost region from the centers of political decision making. Despite this background, Galicia continued to be economically relevant in the Late Middle Ages, thanks not only to its dense population, but also to its geographical position as a stopover point on the maritime trade routes between the Atlantic and the Mediterranean [17].

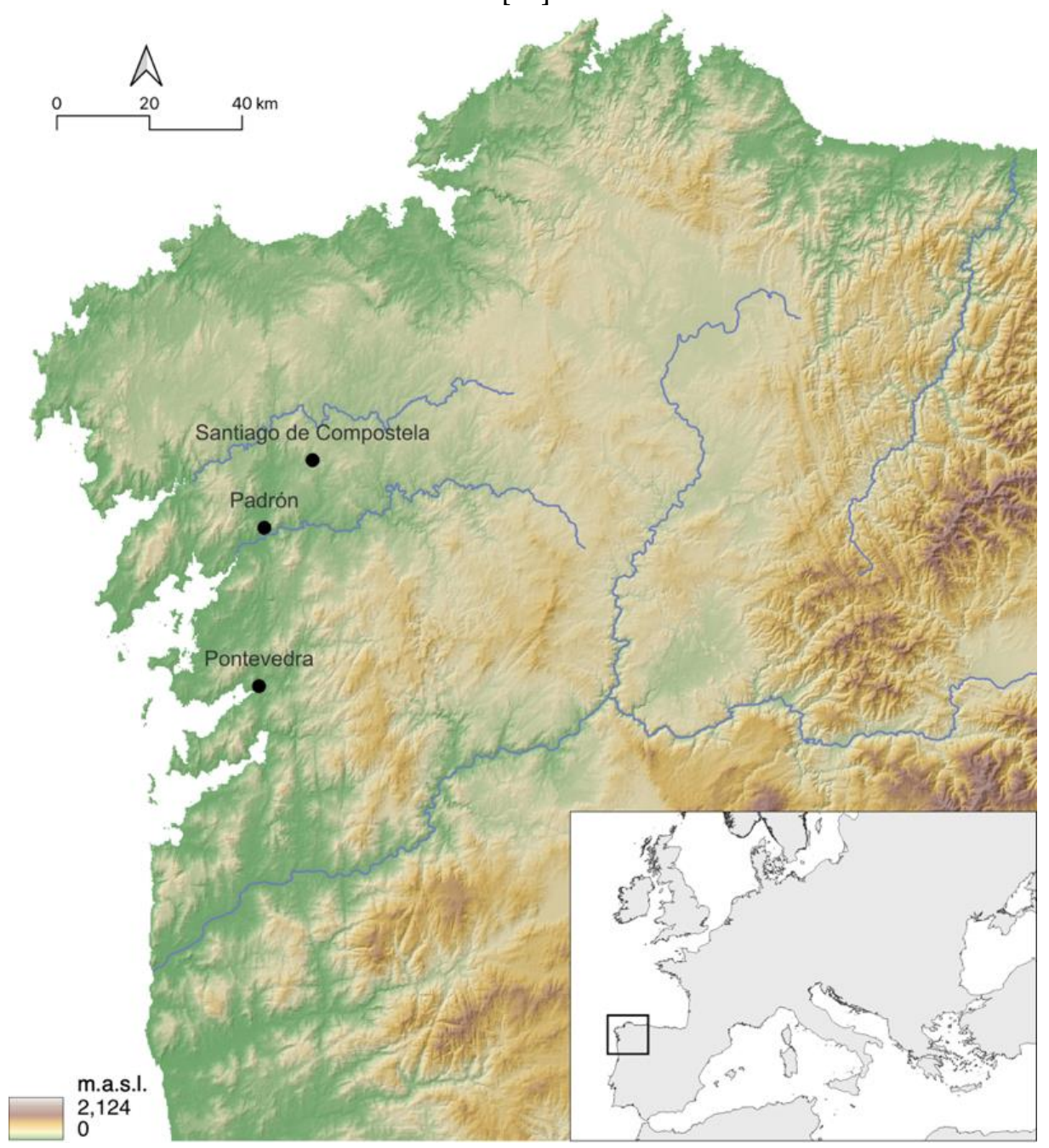

Figure 1. Location of the medieval towns with waterlogged archaeobotanical assemblages discussed in the text (map by Andrés Teira-Brión).

The manor was the basic unit of agrarian organization in the Middle Ages; it consisted of an agricultural estate, large or small, over which lordship was exercised by a layman, the Crown, or an ecclesiastical institution [18, 19]. Manors were usually managed by members of the client networks of the lord's house or institution, linked to it by a feudal or vassal bond [20]. Much of the agrarian production of the villagers was, nevertheless, beyond their control and had to be negotiated with the lord of the manor, who had different prerogatives (acquired by privilege). Farmers were tied to the land by long-term or perpetual contracts (foro), for which they paid rent. In this way, they maintained a personal and economic dependence, as well as a submissiveness that limited their status as free people by denying them a minimum of autonomy of movement [21]. It is the gentry and merchants who distributed these villagers' agricultural production on a supra-local scale, acting as intermediaries between producers and consumers [22]. But peasants must 
not be perceived to have played an exclusively passive role, as they had the capacity to sell their products at local markets.

\subsection{Brief Overview of Medieval Agriculture}

Our knowledge of agriculture in medieval times has mainly been based on mentions of crop production in written sources. The manorial documents, habitually of ecclesiastical [23] or commercial [2] provenance, are a testimony of the land contracts, norms and production conditions in which cultivation was framed. The books on agriculture written by authors born in Al-Andalus [24-26] are another valuable source of information, although they provide a portrait of the Muslim area of the Iberian Peninsula only. Nevertheless, despite this wealth of information, the written sources often reflect the preference or desire of the ruling class for crops that commanded a high market value. Exceptionally, this elite literature include the habits of the popular classes [27] or mentions those products whose economic value is lower, usually associated with highly perishable or barely processed foods. In fact, the names of garden or orchard species are not usually recorded [28]. Therefore, claims based solely on manorial documents and treatises of agriculture can mask regional or social group-based divergences.

In recent years, the study of late medieval agriculture has encompassed new archaeological approaches, which have focused on defining farming structures, such as terracing $[29,30]$ or irrigation structures [31], or on how the medieval communities modeled the landscape they inhabited [32]. Meanwhile, archaeobotanical research is becoming particularly dynamic, thanks to new developments in archaeological site studies [33-35] and thanks to holistic or synthesis publications that aim to overcome the fragmentary character of site analyses [36-38]. Among the advances that can be glimpsed is the questioning (and sometimes rejecting) of the assertions made in works based exclusively on written sources, as well as the assessment of the importance of certain species. Thus, some of the crop introductions attributed to the Muslims thanks to the theories of A.M. Watson [39] have been criticized in more recent works, which show how some of them had been cultivated before the Arab expansion to the West [40, 41]. Furthermore, there are ambiguities in written sources that need to be explained on a case-by-case basis. For example, sorghum is absent in the archaeobotanical samples [36], despite being mentioned by the geographer al-Bakri as the most important archaeological foodstuff in Galicia [42, 43]. This discrepancy may be due to sorghum being confused with broomcorn millet or foxtail millet, both crops widely known in the medieval period [44].

The majority of the plant-based evidence preserved in archaeological sites comes from charred remains [36], whose preservation is intimately linked to fire events. However, charring results in a data bias by favoring the preservation of certain evidence, such as that of cereals. Hence, carpological analysis of waterlogged material is central to completing the information about agricultural practices and foodstuffs in medieval studies. Although the preservation of organic remains is also biased, wet sites are particularly rich, enabling the recovery of a large number of plants remains. This is why, in the current state of research, each new archaeobotanical analysis constitutes an essential update to our approach to medieval farming.

\section{Results}

Archaeobotanical assemblages from the 11th-14th centuries CE collected in Santiago de Compostela, Padrón, and Pontevedra provide an insight into the commercial cultivation of the Middle Ages in the northwestern territory of the Iberian Peninsula (Galicia). The samples studied come from diverse urban environments: the ditch running along the outside of a fortification wall (Banco de España, Santiago de Compostela); an agricultural establishment in the urban suburbs (O Bordel, Padrón); and a harbor (Ponte do Burgo and Arcebispo Malvar, Pontevedra). The combined dataset comprises more than 2 million macroremains belonging to 19 economic plant taxa and 37 wild taxa (TableS1, TableS2). The majority of specimens are preserved by waterlogging, although some charred plant remains are also present. 
The seeds and fruits recovered ended up in these deposits as the result of social networks and the transport of agricultural products that reached the cities for various reasons, such as serving as foodstuffs or as market products for redistribution. These factors have led to the identification of cash crops (Figure 2, Table 1) related to the processing of cereals, fruit trees usually grown in orchards on family farms, and of several plant taxa usually associated with garden plots. Pulses are absent from the samples analyzed.

\subsection{Cereals}

Cereals are the most abundant remains (Table 1). The largest concentrations of broomcorn millet (Panicum miliaceum) are evidence of its origin as a by-product of crop processing practices. Finds of this cereal can be categorized into assemblages with high fragmentation, and subsequent reduction to very small fragments, of the paleas and upper lemmas (O Bordel and Banco de España), and assemblages with lower fragmentation as well as still attached paleas and upper lemmas (Ponte do Burgo and Arcebispo Malvar). In the samples from Banco de España, the remains are mostly broomcorn millet, mixed with a small proportion of foxtail millet (Setaria italica), which could represent an inclusion within the broomcorn millet crop.

Within the Ponte do Burgo samples, two types of broomcorn millet were identified, distinguishable by the color of the covers. These types may be related to at least two different varieties of this crop: one type with a yellow color and another type with a dark brown color (Figure 2). The paleas/upper lemmas still attached in sample 15B-E4 represent $91.61 \%(n=142)$ of the yellow type and $8.39 \%(n=13)$ in the dark brown type.

The other cereals were recovered in significantly smaller quantities. These include a single grain of naked wheat (Triticum aestivum/durum) preserved by charring from O Bordel; grains of oat (Avena sp.) recovered at Banco de España and Ponte do Burgo; and fragments of rye (Secale cereale) rachis at Ponte do Burgo. Although it has not been possible to determine whether they correspond to historically cultivated varieties (Avena sativa, Avena strigosa, Avena nuda), oats were widespread during the Middle Ages and the ones in our samples are considered to belong to this group. In addition to the aforementioned species, fragments of Poaceae stems have been found, possibly from some of the identified cereals (Table S1).

\subsection{Fruits}

Fruits of tree and shrub species were identified recurrently in the samples from the three towns analyzed. These are the cash crops with the greatest diversity and include such fruits as those of grapevine (Vitis vinifera), cherry (Prunus avium), chestnut (Castanea sativa), walnut (Juglans regia), fig (Ficus carica), apple (Malus domestica), plum (Prunus domestica), peach (Prunus persica), and medlar (Mespilus germanica). We were not able to establish a cause for the high fragmentation of the fruits of some species (Castanea sativa, Juglans regia, and Prunus persica). The frequency of the different fruits indicates how widespread their consumption, or the consumption of their derivatives, was. In the archaeological sites of Pontevedra, fragments of leaves and shoots of vine have been found together with Vitis seeds, possibly indicating local growing of grapevine within or in the vicinity of the town.

\subsection{Garden Crops}

Although few in quantity, the remains of such species as turnip (Brassica rapa), melon (Cucumis melo), and spinach (Spinacia oleracea) reflect the fact that agriculture was practiced in intensive cultivation areas, such as gardens. Melon has been found in all three towns, indicating that it was a widespread species. Also significant is the recovery of an exceptional collection of 1,799 seeds of turnip from a single deposit during the excavation of Ponte do Burgo (Pontevedra), thanks to the good preservation of their seed coats, of which only one cotyledon survived. 
a)

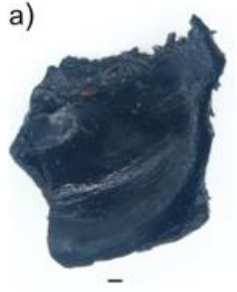

f)

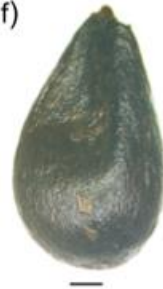

j)

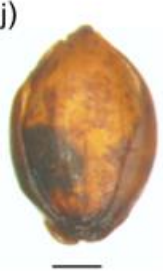

o)

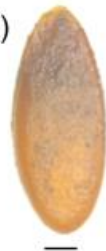

b)

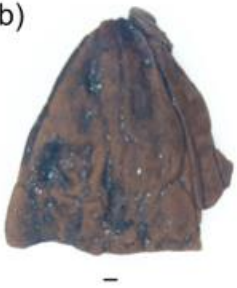

g)

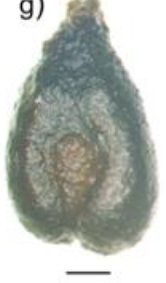

c)

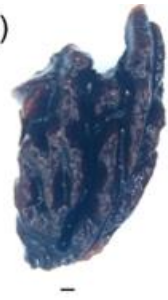

d)

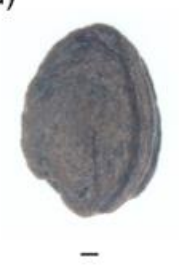

h)

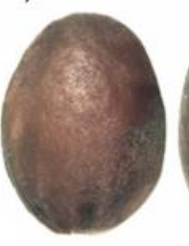

I)

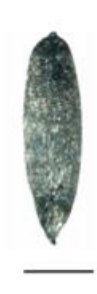

q)

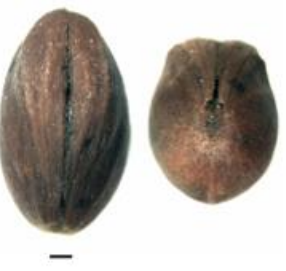

m)

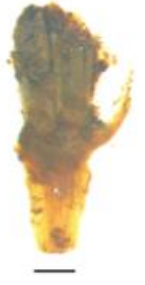

k)

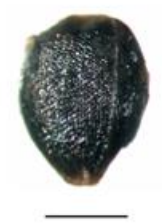

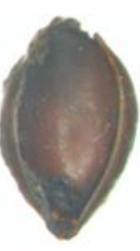

p)

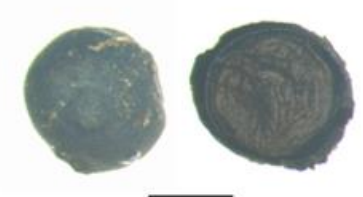

e)

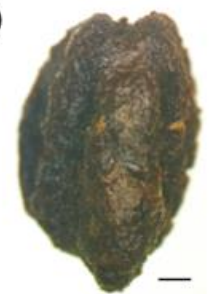

i)

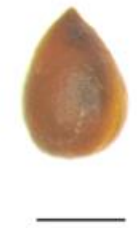

n)

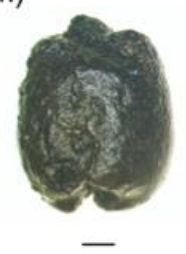

Figure 2. Cash crops present in the archaeobotanical assemblages: (a) pericarp of Castanea sativa; (b) endocarp of Juglans regia; (c) fragment of endocarp of Prunus persica; (d) endocarp of Prunus domestica; (e) seed of Mespilus germanica; (f) seed of Malus domestica; (g) seed Vitis vinifera; (h) endocarp of Prunus avium; (i) infructescence of Ficus carica; (j) upper lemma and palea of two varieties of Panicum miliaceum; (k) palea of Setaria italica; (1) Avena sp.; (m) internode of Secale cereale; (n) deformed charred grain of Triticum aestivum/durum; (o) seed of Cucumis melo; (p) testa and cotyledon of Brassica rapa; and (q) round fruit of Spinacia oleracea. Remains from Banco de España (h, $k$, and 1), O Bordel (e, f, g, i, and n), Ponte do Burgo (j, m, p, and q), and Arcebispo Malvar (a, b, c, and d). Scales: $1 \mathrm{~mm}$ (pictures by Andrés Teira-Brión).

\subsection{Weeds, Ruderals, and Wild Plants}

Concerning wild flora (Table S1, Table S2), the species identified represent a diversity of ecological niches, influenced to a greater or lesser extent by anthropic factors. Most of the taxa found are weeds of communities that proliferate in association with cereal crops (Chenopodium album, Lolium perenne/rigidum, Medicago sp., Polygonum lapathifolium, Polygonum persicaria, Portulaca oleracea, Rumex sp.). Among the remains of these weed species, Lolium perenne/rigidum caryopses are the only ones recovered in charred form. Other plants found are common in ruderalized areas, pastures, road margins, or anthropized areas (Centaurium pulchellum, Glebionis segetum, Raphanus raphanistrum, Silene gallica, Stellaria media, Trifolium sp., Urtica urens). We also identified species that proliferate in humid soils (Sambucus nigra) or are favored within forest and scrubland communities (Pteridium aquilinum, Pinus sp., Ulex sp.). The seeds of blackberry (Rubus fruticosus) in the samples from Pontevedra are interpreted as being the result of natural inclusion rather than harvesting by humans. Although the blackberry produces edible fruits, it is also a species that grows naturally in nutrient-rich soils. The frequency of its seeds in the samples from this town could be due to communities of this plant growing on the banks of the river. Although the use of Rubus fruticosus as food cannot be ruled out, human consumption cannot be inferred from the assemblages studied. 
Table 1. Summary of remains of cash crops from the sites discussed in the text. See 4.2. Methods for counts of Panicum and Setaria taxa. ${ }^{*}=$ charred remains; frag. $=$ fragment; up. $=$ upper $)$.

\begin{tabular}{|c|c|c|c|c|c|c|c|c|c|c|c|c|c|}
\hline \multirow[b]{2}{*}{ Group } & \multirow[b]{2}{*}{ Scientific Name } & \multirow[b]{2}{*}{ Plant Part } & \multirow{2}{*}{$\begin{array}{c}\begin{array}{c}\text { Banco } \\
\text { de Es- } \\
\text { paña }\end{array} \\
24 E\end{array}$} & \multirow{2}{*}{$\begin{array}{c}\begin{array}{c}\text { O Bor- } \\
\text { del }\end{array} \\
\text { E-143-1C }\end{array}$} & \multicolumn{2}{|c|}{$\begin{array}{c}\text { Ponte do } \\
\text { Burgo }\end{array}$} & \multicolumn{6}{|c|}{ Arcebispo Malvar } & \multirow[t]{2}{*}{ Total } \\
\hline & & & & & $\begin{array}{c}\text { 15B- } \\
\text { E4 }\end{array}$ & $\begin{array}{c}\text { 15B- } \\
\mathrm{J} 7\end{array}$ & 1404 & 1216 & 1218 & 1219 & 1220 & 1221 & \\
\hline \multirow[t]{11}{*}{ Cereals } & Avena sp. & Seed & 1 & & & 1 & & & & & & & 2 \\
\hline & \multirow{4}{*}{$\begin{array}{l}\text { Panicum milia- } \\
\text { ceum }\end{array}$} & Seed & & & 1 & & & & 1 & & & & 2 \\
\hline & & Palea/up. lemma & & & 509 & 91 & 4 & 2 & 1 & 2 & 2 & & 611 \\
\hline & & $\begin{array}{l}\text { Palea/up. lemma } \\
\text { (still attached) }\end{array}$ & 24 & 32 & 155 & 25 & 2 & & 2 & 2 & & & 242 \\
\hline & & $\begin{array}{c}\text { Palea/up. lemma } \\
\text { frag. }\end{array}$ & & $1,743,744$ & & & & & & & & & $1,743,744$ \\
\hline & Panicum/Setaria & $\begin{array}{c}\text { Palea/up. lemma } \\
\text { frag. }\end{array}$ & 262,240 & & 18,046 & & & & & & & & 280,286 \\
\hline & \multirow[t]{3}{*}{ Secale cereale } & Rachis 4 internodes & & & 1 & & & & & & & & 1 \\
\hline & & Rachis 3 internodes & & & 2 & & & & & & & & 2 \\
\hline & & Rachis 1 internodes & & & 1 & & & & & & & & 1 \\
\hline & Setaria italica & Palea & 2 & & & & & & & & & & 2 \\
\hline & $\begin{array}{l}\text { Triticum aes- } \\
\text { tivum/durum }\end{array}$ & Seed & & $1^{*}$ & & & & & & & & & 1 \\
\hline \multirow[t]{4}{*}{ Garden } & Brassica rapa & Testa & & & & 1,799 & & & & & & & 1,799 \\
\hline & \multirow[t]{2}{*}{ Cucumis melo } & Seed & 3 & 6 & & & & & 1 & & & & 10 \\
\hline & & Seed frag. & & & & & 1 & & & & & & 1 \\
\hline & Spinacia oleracea & Fruit & & & 1 & & & & & & & & 1 \\
\hline \multirow[t]{13}{*}{ Fruits } & Castanea sativa & Pericarp frag. & 3 & & 5 & 9 & 24 & 7 & 18 & 6 & 1 & 2 & 75 \\
\hline & Ficus carica & Infructescence & 137 & 2,724 & 54 & 13 & 93 & 157 & 327 & 283 & 66 & 32 & 3,886 \\
\hline & Juglans regia & Endocarp frag. & & & & & 15 & 23 & 33 & 23 & 2 & & 96 \\
\hline & Malus domestica & Seed & 3 & 3 & & & & & & & & & 6 \\
\hline & $\begin{array}{l}\text { Mespilus german- } \\
\text { ica }\end{array}$ & Endocarp & & 19 & & & & & & & & & 19 \\
\hline & \multirow[t]{2}{*}{ Prunus avium } & Endocarp & 364 & 2 & & & 1 & & & & & & 367 \\
\hline & & Endocarp frag. & 28 & & 1 & & 1 & & 6 & 2 & 1 & & 39 \\
\hline & Prunus domestica & Endocarp frag. & & & & & & & 1 & 1 & & & 2 \\
\hline & Prunus persica & Endocarp frag. & & & 6 & & & & 3 & & & & 9 \\
\hline & Prunus sp. & Endocarp frag. & & & 3 & & & & & & & & 3 \\
\hline & \multirow[t]{2}{*}{ Vitis vinifera } & Seed & & 6 & 17 & 8 & 13 & 13 & 8 & 5 & & 1 & 71 \\
\hline & & Seed frag. & & & 3 & 2 & 2 & 1 & 2 & & 1 & & 11 \\
\hline & Total & & 262,805 & $1,746,537$ & 18,805 & 1,948 & 156 & 203 & 403 & 324 & 73 & 35 & $2,031,289$ \\
\hline
\end{tabular}

\section{Discussion}

Archaeological excavations carried out in recent years have made it possible to recover assemblages of seeds and fruits from urban contexts, which provide evidence of the crops grown in the Kingdom of Galicia during the Late Middle Ages. The four archaeological sites, which include various urban contexts where crop residues that reached the city were dumped (such as a rubbish dump, a cesspit/dump, and a harbor environment), are excellent examples of the wealth of information that can be inferred from wet sites. This information allows us to theorize about the role of the city within the agricultural system, and how the flow of crops it receives can have different causes and purposes. 


\subsection{Novelties in the Medieval Archaeobotanical Record of the Iberian Peninsula}

Three of the crops identified from the sites discussed here were not yet known from the archaeobotanical record of the Iberian Peninsula, and they allow us to establish that turnip, spinach, and medlar were present in medieval times. Although plants of the Brassicaceae family are frequently mentioned in the texts of Roman authors $[45,46]$ and also in medieval times, large assemblages tend to be exceptional in archaeobotanical samples [47], even though some varieties of Brassicaceae have been used for oil production since ancient times. This lack of large assemblages is perhaps due to the small number of seeds needed for reproduction. The Ponte do Burgo excavation yielded a set of preserved Brassica rapa seed coats which may correlate with turnips or with a leafy green crop called grelo in Galician. According to recent genetic work on Brassica rapa varieties, the grelo variety split from independently selected local Iberian turnips roughly 730-930 years before present [48]. These two varieties of the same species imply different food uses. Both the edible roots and the leaves of turnips are eaten, while only the leaves of grelos are consumed.

The introduction of spinach to Europe is attributed to the Arabs, who are said to have expanded its cultivation from the Iberian Peninsula [49]. Spinach is mentioned in the Kitâb al-filâha (Book of Agriculture), a treatise written by Ibn al-'Awwâm that refers to agricultural practices in Andalusia in the 11th and 12th centuries CE [50]. Despite consisting of only a single fruit, the find from Peirao da Ponte (Pontevedra) makes it possible to fill in the information gap that had existed for the end of the Middle Ages in the Iberian Peninsula, although its date (13th-14th CE), being later than finds from the south of France [51], does not allow us to confirm or disprove the hypotheses about the dispersion of spinach. However, Pontevedra was commercially connected to other places where spinach seeds have been found from the 13th to 15th centuries, such as the Netherlands and Germany [51], so the sea could also have played an important role in the dispersal of this and other crops.

The medlar fruit is only edible after rotting, which can be a natural or an induced process. The only published reference to Mespilus germanica within the Iberian Peninsula so far is to 16th century seeds from the wet site of Panpinot, in the Basque Country [52]. Therefore, the O Bordel assemblage is currently the oldest known context containing this fruit (11th-12th centuries CE) in Iberia, but it is likely that it was introduced even earlier, as the medlar is a fruit tree that was known in other regions of Europe during Antiquity [53].

\subsection{The Town as Consumer}

The towns of Galicia were the recipients of a wide variety of grains and fruits supplied from the hinterland. The foodstuffs and agrarian products that reached a place such as Pontevedra derived mainly from the nearby countryside, no more than 20-30 kilometers away [8]. Grain was essential to urban life, and, to ensure its availability, storage capacity was intensified by the construction of silos and granaries, often owned by a social group with high purchasing power or by institutions that supplied them [54-56].

Despite the proportion of subfossil cereal chaff being high in waterlogged deposits [57], the documented assemblages of millet may relate to the existence of one or several processing locations within the urban centers, and these crops may have been transported husked. The majority of the analyzed assemblages comprise highly fragmented broomcorn millet chaff, which is consistent with ethnographically documented grain dehusking in the region [58]. However, in the Ponte do Burgo samples, the upper lemmas and paleas were mostly found intact, possibly indicating that they had not yet been dehusked. The importance of millet in the diet has been revealed through isotopic analysis [59] and through study of the written sources [8]. The isotopic signature of the bones from the burials in the Pontevedra cemeteries indicates that the inhabitants of the city ate a mixed diet of terrestrial and marine foods, based on C3 plants but with a significant contribution of C4 plants (i.e. millet) [59].

Differences in the coloring of broomcorn millet grains have been noted in type specimens with a similar variability to the current traditional crops of northwestern Iberia [58]. However, color is not necessarily a determining trait for the variety, and it may be a 
variable characteristic within the same population. Another factor to consider is that the differences in the coloring among paleas and lemmas relate to the physical-chemical conditions of the archaeological context where the remains were deposited. Genetic analysis of the archaeological remains will be necessary to confirm the hypothesis of different millet populations.

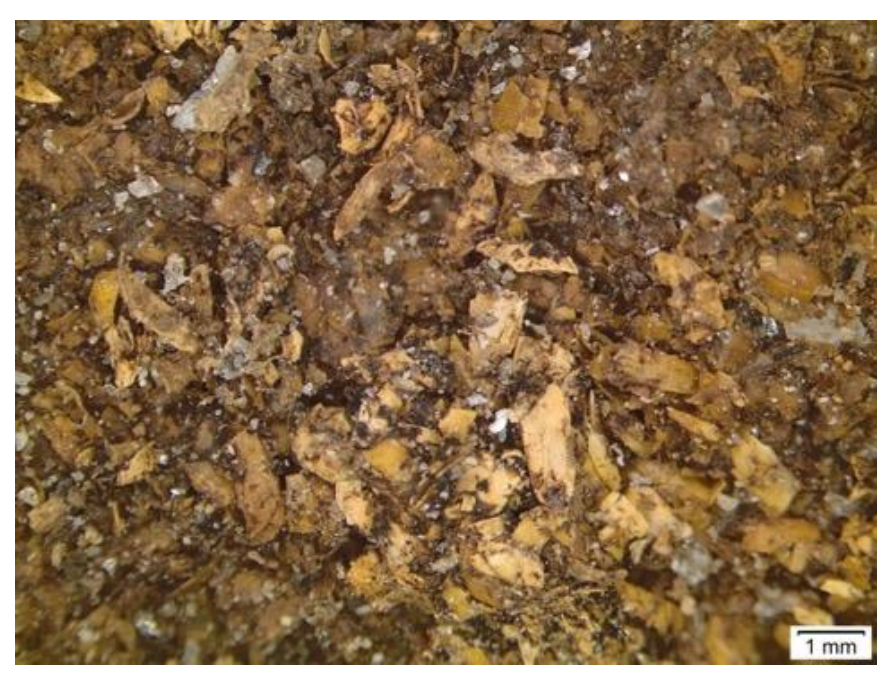

(a)

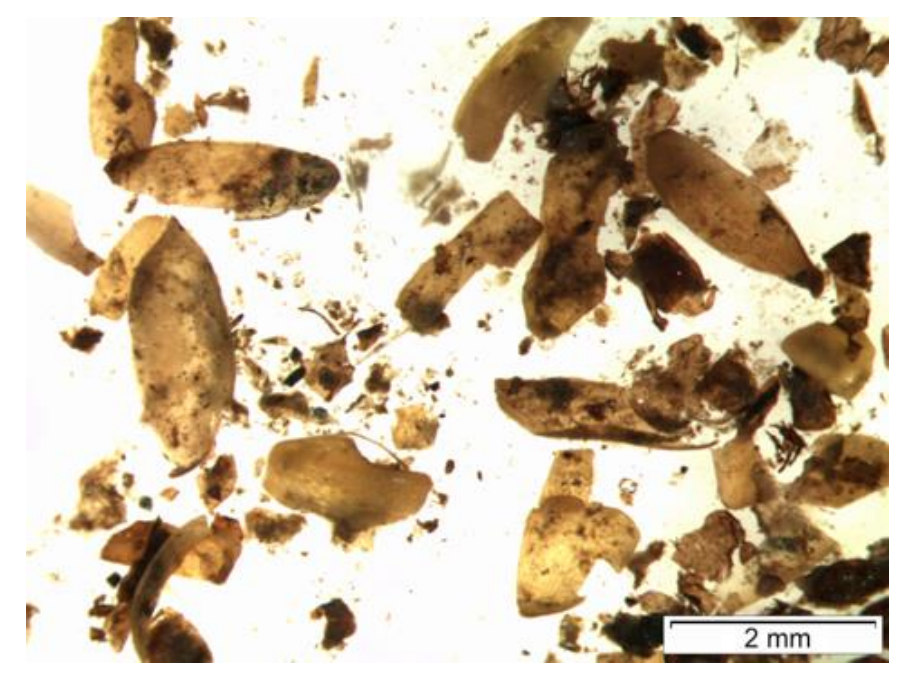

(b)

Figure 3. Fragmented upper lemmas and paleas of Panicum miliaceum: (a) as seen in the O Bordel bulk sample; (b) as seen during sorting of the Banco de España sample within a sheet of water (pictures by Andrés Teira-Brión).

The humid environment that favored the preservation of millet in the samples may have produced a bias in the representativeness of other crops. We speculate that the scarcity of caryopses of oat (Avena sp.) and wheat (Triticum aestivum/durum), and of the rachis of rye (Secale cereale), may be explained by the poor preservation of cereal grains under waterlogged conditions [57,60], since archaeobotanical data from producer agricultural sites and forts with remains preserved by charring suggest that all of the above-mentioned cereals (along with millet) were well-known and widespread crops in northwestern Iberia at the time [61-65].

Garden and orchard species are often invisible in historical documentation, as they are often unmentioned. We know from carpological findings that the consumption of fresh or processed fruit played an important role in the urban diet. In the orchards or farms near each production unit, that is, the house, space was reserved for cherry, apple, walnut, chestnut, and fig trees, among other species. These orchards and gardens were usually fenced or surrounded by walls or hedges integrated into the inhabited nuclei, and served as a source food supplement within the reach of the usufructuary of the land [66]. The nobility also requested the planting of fruit trees of economic interest as payment for contracts (foro). In these documents, we find frequent mention of the opening up of areas of woodland for the cultivation of vineyards and chestnut groves [66, 67].

\subsection{The Town as Producer}

Not all the crops consumed in the towns were grown outside its enclosed area. Some towns had gardens in their interior, and on the outskirts, the cultivated fields reached as far as the town walls. In fact, the presence of small vegetable gardens and animals is characteristic of the urban habitat of medieval Galicia. Monumental architecture and dwellings, some of the latter being precarious constructions, shared space with privately owned cultivation areas or those belonging to ecclesiastical institutions [68]. Many urban planning competences were assigned to the town councils, as was the responsibility for water supply and distribution [5]. In some of the ordinances of the town councils, we see how some neighbors made use of the picaresque to irrigate crops. For example, in Santiago de 
Compostela, it was explicitly forbidden to divert water from the pipes that fed the fountains but which some individuals ended up using in their houses and gardens [69].

The produce from orchards and gardens provided a nutritional supplement to urban dwellers [37]. These plots may be the original source of some of the wild plants found in the studied archaeobotanical assemblages, such as the gorse (Ulex europaeus) and common bracken (Pteridium aquilinum) in the Banco de España samples. Gorse and common bracken could have been brought to the city to be used as livestock bedding and as a source of manure and soil fertilizer, among other uses [70]. We cannot reject the possibility that some fruit trees were grown inside the towns. For example, vine shoots found in the Pontevedra archaeological sites allow us to conjecture about the existence of small vineyards. In any case, although it is essential to consider urban cultivation spaces, their production would have been insufficient to supply the town's population, and most of the remains found in the samples (particularly cereals) would have originated in the countryside.

\subsection{The Town as Distributor}

During the Late Middle Ages, the sphere of Galicia's commercial relations expanded, and its merchants acted as intermediaries and exporters. Both Pontevedra and Padrón were active commercial ports, and although Santiago was landlocked, it had access to the maritime traffic thanks, initially, to its relationship with the river port of Padrón and, later, with the town of Noia. Furthermore, Santiago, Padrón, and Pontevedra were also well connected by terrestrial routes, which had been established in Roman times, when the three towns were first founded. The Peirao da Ponte of Pontevedra is an example of a port with an intense movement of goods, which served as a stopover for navigation between the Atlantic and the western Mediterranean [2]. The dating of the remains from Arcebispo Malvar and from Ponte do Burgo deposited in the river Lérez (Table 3) coincides with a period of mercantile effervescence, and the dumping of waste into the river relates both to the consumption of the urban domestic units and to trade through its docks.

Medieval cities were important in the dispersal of plant species. Products and people from different origins arrived at their markets, shaping them as places not only for trade but also for the exchange of knowledge and ideas. Written sources mention the arrival and departure of agricultural products through the ports and how exports and imports were regulated by laws and commercial agreements. One example is the permission granted to Galicia by the Courts of Valladolid in 1351 to sell broomcorn millet, oat, chestnuts, and fruits in Portugal, while at the same time prohibiting the sale of other cereals [2]. Products such as grain and wine were a frequent cargo on ships sailing the Atlantic. The volume of grain fluctuated according to the economic and political situation, and it was both imported from outside the Peninsula (e.g., from France) and exported from other regions of the kingdom such as Castile [2]. Wine arrived in Pontevedra from the Mediterranean regions of the Iberian Peninsula, and the locally produced wines from the region of O Ribeiro were exported to France or Great Britain from its docks [2, 71]. This commercial framework shows the vitality of ports as nodes for the expansion and supply of a wide range of agricultural products over long distances, something that is observed not only in Galicia, but also in other European territories [72]. This trade was generally associated with crops, although some archaeobotanical studies have pointed to the importance of trade networks in the dispersal of wild fruits and berries consumed in medieval towns $[52,72]$.

O Bordel was another possible distribution point for agricultural products. Although it has been interpreted as a farm [73], the archaeological evidence does not necessarily correspond to self-sufficiency with respect to agriculture, given the concentration of silo structures and of excavated pits reused as rubbish dumps, and the large quantities of associated pottery. Another possible explanation for $\mathrm{O}$ Bordel is that it is either an exploitation designed to market surpluses or an area for redistribution of products, received from farms and linked to the supply of the town of Padrón or some manorial institutions. This 
would allow us to make sense of the similarities of the crops found with the other urban contexts studied and of the diversity of structures and materials at the site.

\section{Materials and Methods}

\subsection{Materials}

The seeds and fruits included in this work come from archaeological rescue excavations carried out to document structures and other evidence affected by different construction projects in recent years. The archaeobotanical materials come from wet environments from High and Late Middle Ages levels in the cities of Santiago de Compostela (Banco de España), Padrón (O Bordel), and Pontevedra (Ponte do Burgo and Arcebispo Malvar Street) (Table 2). The vast number of archaeobotanical remains of fruits and seeds and other parts of plants recovered (2,031,737 remains) were mostly preserved in waterlogged condition (2,031,727 remains, TableS1). Charred seeds were also found, but in significantly smaller quantities (10 remains, TableS2).

Table 2. Overview of the archaeobotanical samples. See 4.2 Methods for counting. (SU = stratigraphic unit).

\begin{tabular}{|c|c|c|c|c|c|}
\hline City & Site & SU & $\begin{array}{c}\text { Number of } \\
\text { Samples } \\
\end{array}$ & Volume (L) & $\begin{array}{c}\text { Total Number } \\
\text { of Remains }\end{array}$ \\
\hline Santiago de Compostela & Banco de España & $24 \mathrm{E}$ & 1 & 0.50 & 262,848 \\
\hline Padrón & O Bordel & E-143 & 1 & 1.00 & $1,746,598$ \\
\hline \multirow{8}{*}{ Pontevedra (Peirao da Ponte) } & \multirow{6}{*}{ Arcebispo Malvar } & 1404 & 1 & 2.50 & 197 \\
\hline & & 1216 & 1 & 2.50 & 230 \\
\hline & & 1218 & 1 & 2.50 & 462 \\
\hline & & 1219 & 1 & 2.50 & 381 \\
\hline & & 1220 & 1 & 2.50 & 85 \\
\hline & & 1221 & 1 & 2.50 & 42 \\
\hline & \multirow{2}{*}{ Ponte do Burgo } & 15B-E4 & 1 & 0.68 & 18,932 \\
\hline & & 15B-J7 & 1 & 0.13 & 1,962 \\
\hline
\end{tabular}

Table 3. Radiocarbon dates of some of the samples analyzed, calibrated using Oxcal 4.4 [74] and the IntCal 20 curve [75]. (SU = stratigraphic unit).

\begin{tabular}{cccccc}
\hline Site & SU & $\begin{array}{c}\text { Laboratory Ref- Conventional Radi- Calibrated Age AD (2 } \\
\text { erence }\end{array}$ & ocarbon Age & Sigma) & Material (Seed) \\
\hline Banco de España & $24 \mathrm{E}$ & Beta-317502 & $930 \pm 30 \mathrm{BP}$ & $\begin{array}{c}1032-1178(93.2 \%) \\
1192-1203(2.3 \%)\end{array}$ & Prunus avium \\
\hline O Bordel & E-143-1C & Beta-607845 & $930 \pm 30 \mathrm{BP}$ & $\begin{array}{c}1032-1178(93.2 \%) \\
1192-1203(2.3 \%)\end{array}$ & Mespilus germanica \\
\hline Arcebispo Malvar & 1221 & Beta-607847 & $810 \pm 30 \mathrm{BP}$ & $\begin{array}{c}1178-1191(4.5 \%) \\
1204-1276(90.9 \%)\end{array}$ & Vitis vinifera \\
\hline Ponte do Burgo & 15B (E4) & Beta-442852 & $650 \pm 30 \mathrm{BP}$ & $\begin{array}{c}1281-1328(44.7 \%) \\
1345-1395(50.8 \%)\end{array}$ & Vitis vinifera \\
\hline Ponte do Burgo & 15B (J7) & Beta-607846 & $640 \pm 30 \mathrm{BP}$ & $\begin{array}{c}1285-1330(40.9 \%) \\
1336-1397(54.5 \%)\end{array}$ & Vitis vinifera \\
\hline
\end{tabular}

4.1.1. Banco de España (Santiago de Compostela)

The Banco de España is a building located in the center of Santiago de Compostela, whose renovation (2010) uncovered part of the ditch of the first walled enclosure of the medieval town, built in the 960s, which fell into disuse after the construction of a second wall in 1037-1066. This first ditch was filled with water from various springs [68], but later became clogged as a result of anthropogenic and natural processes of mixed formation. 
During its abandonment, the ditch was used as a rubbish dump by the inhabitants of the town, which, thanks to the existence of aquifers, generated a humid subterranean environment that allowed the preservation of abundant wooden artifacts [76] and other evidence of vegetal origin. The sample, 0.5 liters in volume, was obtained from the interior of a pit excavated in the ditch backfill deposits in contact with a dish made of Castanea sativa wood. The sample has been dated to the 11 th-12th centuries CE (Table 3). The materials from this archaeological site are included in a previous publication, but an amendment for two of the plant identifications is provided here. The remains originally identified as Cucumis sativus have been reidentified as Cucumis melo, and those originally identified as Pyrus/Malus are now identified to a more detailed taxonomic level, as Malus domestica [70].
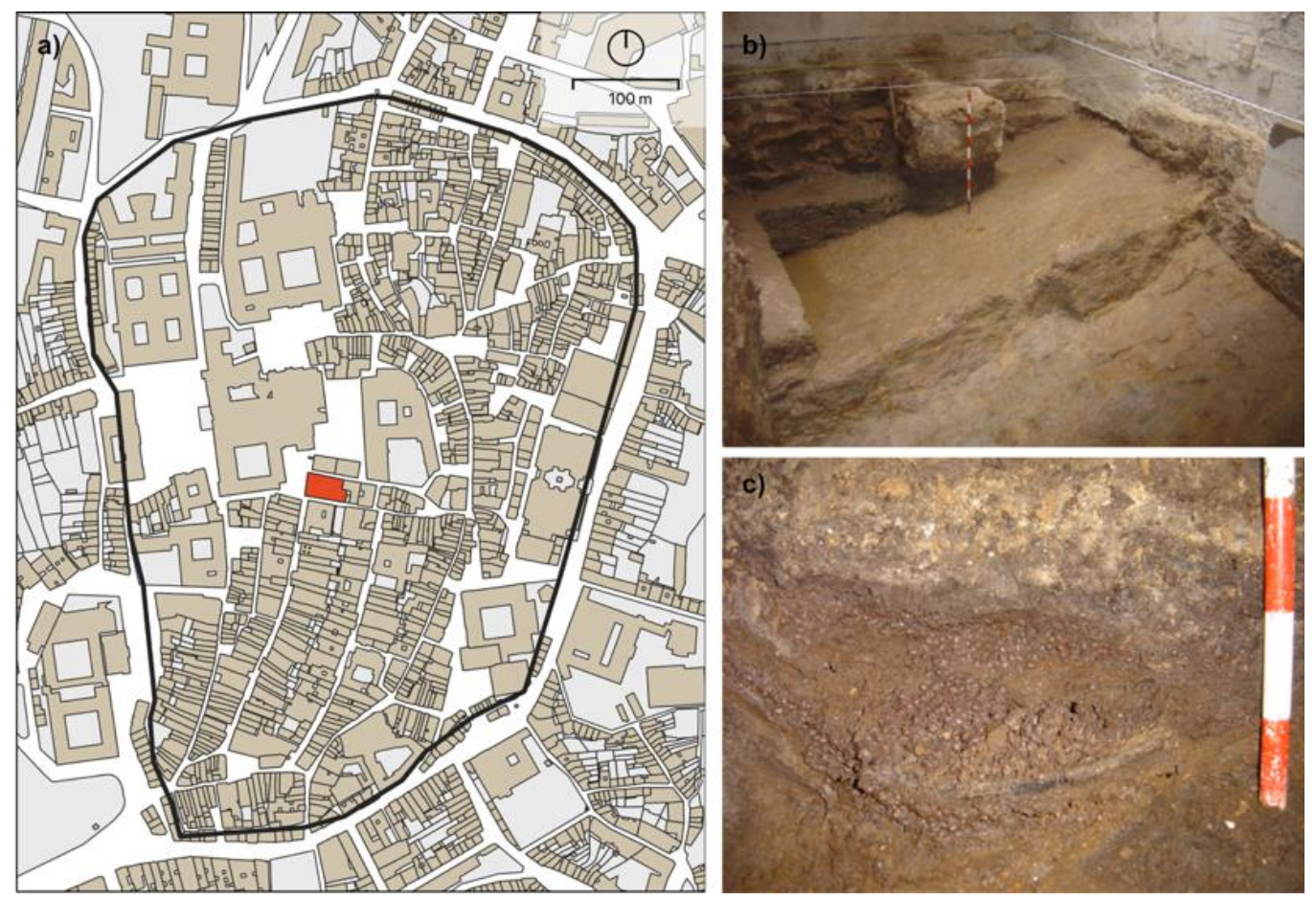

Figure 4. (a) Location of the site of Banco de España (in red) inside the medieval walled town of Santiago de Compostela (map by Andrés Teira-Brión); (b) ditch scarp carved into bedrock; and (c) dish and cherries recovered during the excavation (pictures by Dolores Gil Agra).

\subsubsection{O Bordel (Padrón)}

O Bordel is a suburban area on the outskirts of the walled perimeter of the town of Padrón (formerly Villa Patrono), on a road that connects it with Pontevedra and Santiago de Compostela. The city is also very close to the nucleus of Iria Flavia, a place of Roman foundation that was the seat of a bishopric that officially moved to Santiago de Compostela in 1095, although it has been the habitual residence of bishops since the invention of the tomb of the apostle St. James in the 9th century CE. The archaeological site has been interpreted as a residential space and an attached agricultural production area with an associated storage area, characterized by a concentration of negative structures (trenches and pits), some of which were used for storage (silos) [73]. Radiocarbon dating, some numismatics, and the pottery found indicate a main occupation during the late medieval period $[73,77]$. The sample studied comes from the interior of structure E-143 (Figure 5), which, although originally built as a silo, was later reused as a cesspit, latrine, or rubbish dump. In addition to the archaeobotanical remains included in the present study, a fragment of the structure's lid, made of Castanea sativa wood, has also been recovered from inside the structure [78]. 


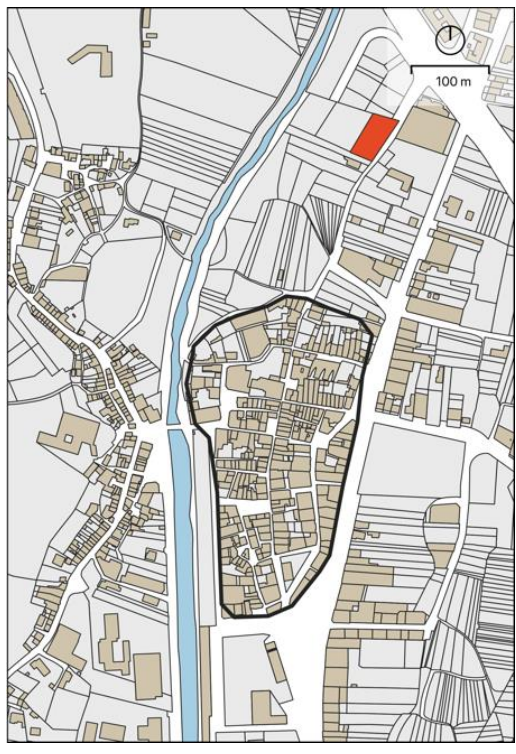

(a)

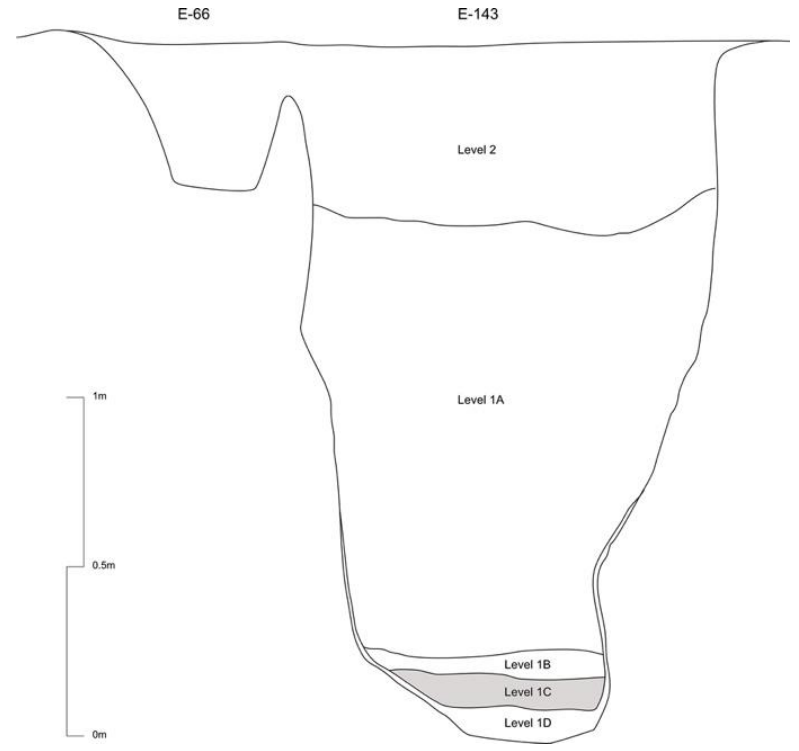

(b)

Figure 5. (a) Location of the site of O Bordel (in red) in the suburb of the medieval walled town of Padrón (map by Andrés Teira-Brión); (b) cross-section of structure E-143 from that site (the sample analyzed came from level 1C, shown in gray) (drawing by Víctor Rúa Carril).

\subsubsection{Peirao da Ponte (Pontevedra)}

Located on the south bank of the river Lérez and close to its mouth, the Peirao da Ponte was the port of the city of Pontevedra [17]. At the end of the Middle Ages, numerous alluvial deposits of natural sedimentation formed, to which were added debris deposited on the riverbank and generated by the activities of the medieval city. This sedimentation and debris caused the river channel to silt up, making it less navigable. To mitigate this situation, structures were built out into the center of the river to allow ships to gain draft. At the beginning of the 16th century, the riverbank was reformed with the construction of a new wall and a dock, and several levels of sediment from the riverbed were encased inside these two structures. From this harbor, several samples were analyzed from two excavations, located 30 meters apart: Ponte do Burgo and Arcebispo Malvar Street (Table 2, Figure 6). Despite the possibility of the existence of in-river transport of materials, the radiocarbon dates of the levels of high concentration of organic materials analyzed are consistent with each other and with the archaeological materials recovered, dating these accumulations of organic material to the 13th-14th centuries CE (Table 3).

- The materials from the Arcebispo Malvar excavation (2014-2016) come from a $60 \mathrm{~cm}$ high column sample taken between the granitic bedrock and the level that delimits the reformation of the post-medieval wall. The deposits in the column were formed during a period of still water with silt deposition, coinciding with the modification of the town's coastline. A total of 12 liters of sediment were processed by wet sieving, 2.5 liters for each of the stratigraphic units delimited at the sampling point in the archaeological excavation.

- From the Ponte do Burgo excavation (2006), a total of 0.81 liters of sediment have been processed, corresponding to two point samples within the same stratigraphic unit, 15B. This deposit was formed by fluvial mud and sand that blocked the medieval dock. The construction of a new wall in the 16th century enclosed the riverbed layers under the fills of the town's extension, allowing the preservation of the materials (Figure 7). 


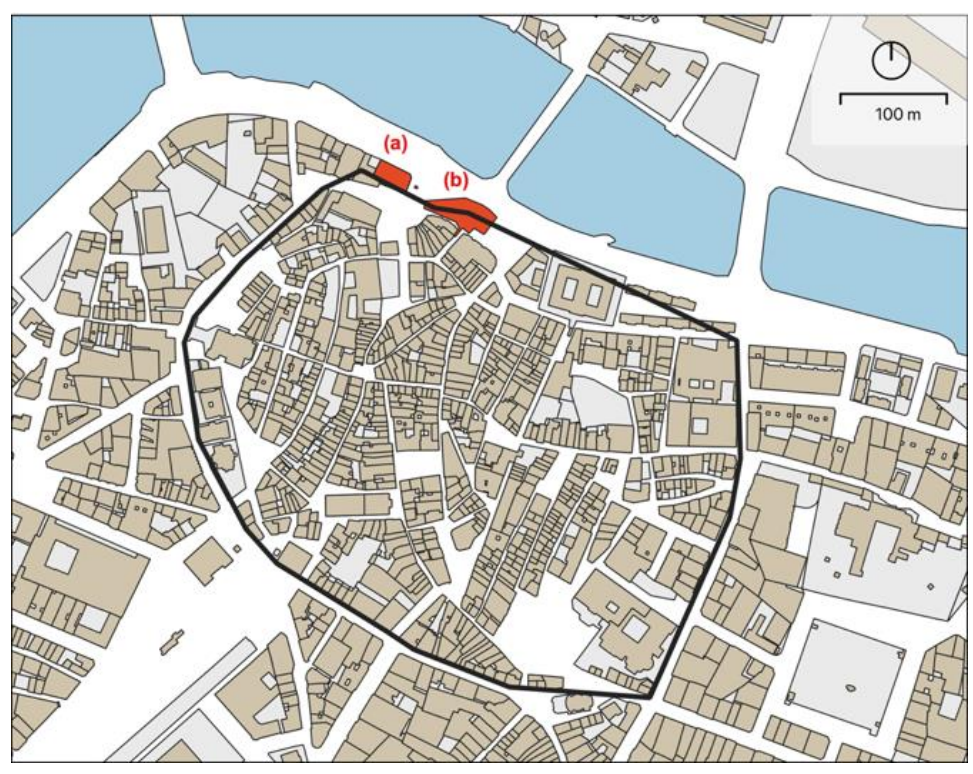

Figure 6. Location of the sites of Arcebispo Malvar (indicated by a) and Ponte do Burgo (indicated by b) in what was the medieval harbor of the city of Pontevedra, on the river Lérez (map by Andrés Teira-Brión).

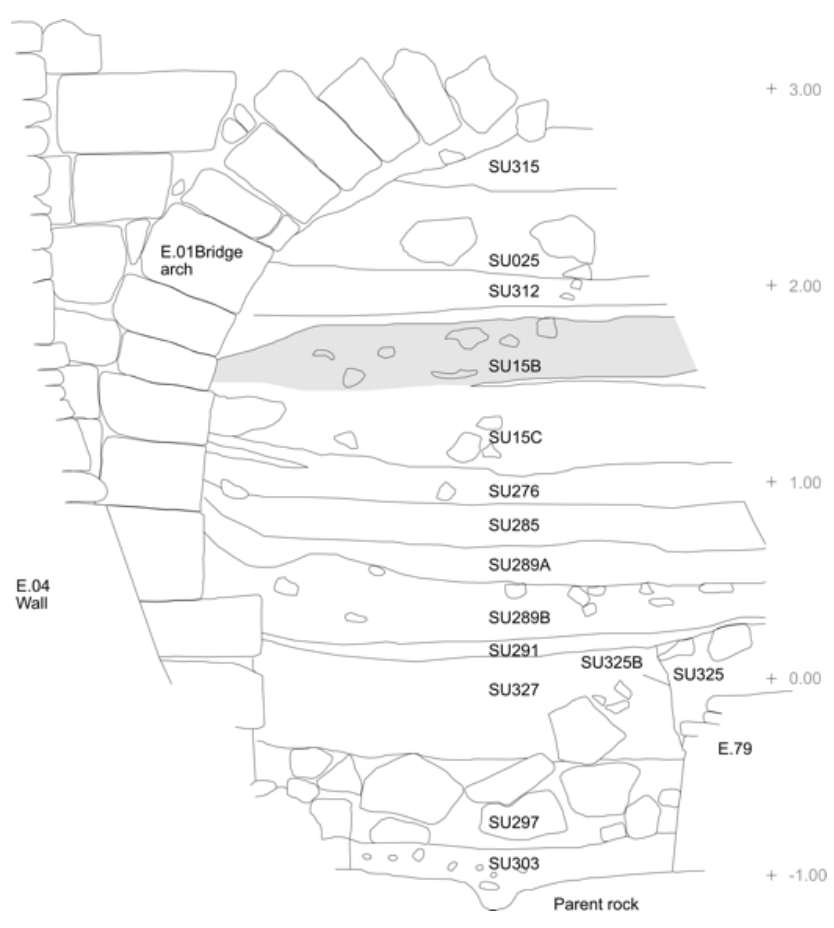

(a)

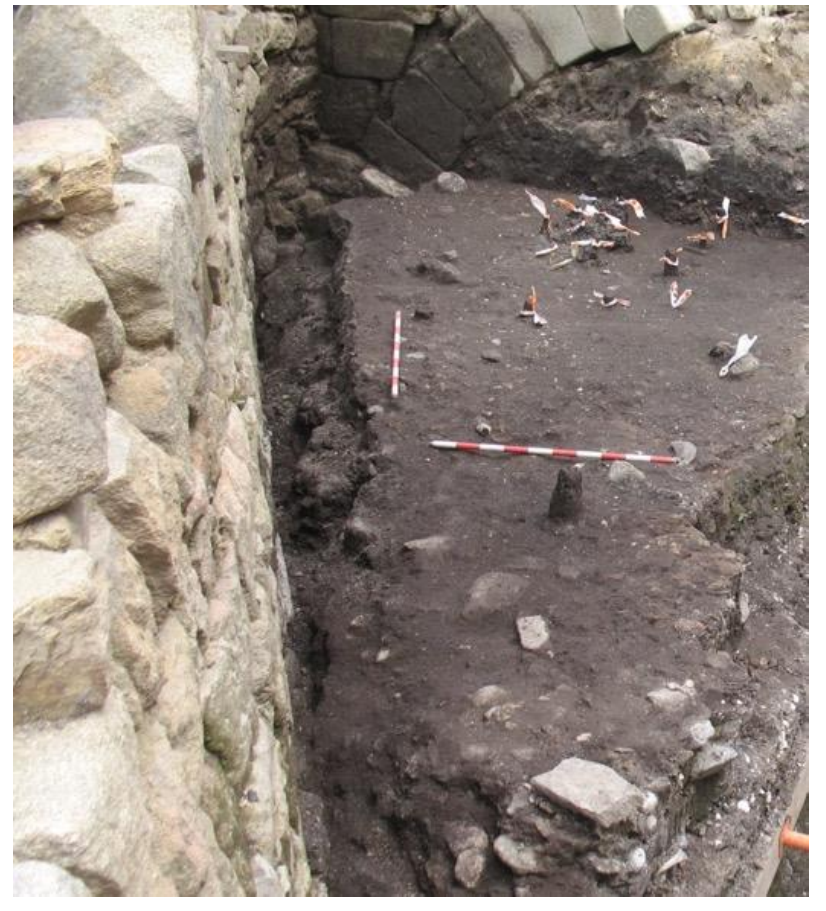

(b)

Figure 7. The site of Ponte do Burgo, in Pontevedra: (a) cross-section of the medieval stratigraphy under the medieval bridge arch (with stratigraphic unit 15B shown in gray (drawing by Xurxo Constela Doce) (b) plan view of stratigraphic unit 15B (right) and the 16th century wall (left) (picture by Xurxo Constela Doce).

\subsection{Methods}

A total of 10 samples were collected within 9 stratigraphic units (Table 2). Generally, sampling was carried out by the archaeologists of each of the archaeological interventions. The purpose of collecting the samples was to recover well-preserved evidence according to the criteria established in each archaeological intervention. Therefore, there was no consistent sampling methodology, and no uniform volume was collected from each excavation context. Only at Arcebispo Malvar was a column sample with a constant volume of 
2.5 liters extracted from the different stratigraphic units. Despite these methodological divergences, we are confident that the samples are representative, as samples of just a few liters have been shown to be indicative of the economic importance of plant remains from wet sites [79]. The remains were mostly separated by wash-over, allowing the separation of organic matter by the movement of water generated in the container, and without applying pressurized water [80]. The sample column from the Arcebispo Malvar excavation was processed by wet sieving. The materials were recovered on sieves of 2, 1, and $0.5 \mathrm{~mm}$ mesh size. The remains were stored in a refrigerator at a temperature of 5 degrees Celsius in airtight, rigid containers to prevent fungal growth and attack by micro-organisms.

The remains were sorted using a binocular microscope under 1-7x magnification, differentiating their state of preservation. This step was carried out with the specimens within a sheet of water to maintain their humidity and, at the same time, to avoid their physical alteration or chemical degradation. For their identification, the seeds and fruits were compared with seeds and fruits held in the modern and archaeological reference collection of the Archaeobotanical Laboratory of the University of Santiago and specialized works of reference, mainly carpological atlases [81-86].

The counting has taken into consideration each preserved part of the plant and whether it was complete (individual) or fragmented. Due to the high concentration of fragments of paleas and upper lemmas of Panicoideae species contained in the samples, only a proportion of the Panicoideae fragments were sorted: 1/16 from Ponte do Burgo and 1/32 from Banco de España and O Bordel. The counts from this sorted portion of the sample were extrapolated to obtain the total of Panicum miliaceum and Panicum/Setaria. The millet remains from the site of Arcebispo Malvar and of the other species from all of the other samples were counted individually.

\section{Conclusions}

The results of this work contribute to a better understanding of the commercial crops that reached the towns of Galicia during the High/Late Middle Ages and not only confirm the importance of cereals in the economy and human diet (particularly broomcorn millet), but also highlight the role of fruit and vegetable garden species, which usually remain obscured in the written sources of this period. The study has documented a local preference for some species for their commercial value. We also found species that are new to the archaeobotanical picture of the Iberian Peninsula, namely turnip/grelo, spinach, and medlar.

Medieval towns established relations with the countryside in order to supply themselves with food and, at the same time, to ensure the basis of their purchasing power and guarantee their position as the center of economic and political life. Thus, these towns were not only consumer centers, but also distributor centers for the products of the rural areas. Cash crops were appropriated by the upper social strata, who controlled the key factors for food production and distribution, namely land, and labor. The ruling class was the largest landowner. Their production was not just intended for local consumption, but was part of a more global economy, feeding it into commercial networks through which they also obtained tax revenues. This commercial exchange may have led to the expansion of crops throughout Galicia, and to the exchange of species and knowledge throughout Europe during the Middle Ages.

Supplementary Materials: The following are available online at www.mdpi.com/xxx/s1, Table S1: Waterlogged remains, Table S2: Charred remains.

Author Contributions: Conceptualization, A.T.B.; methodology, A.T.B.; formal analysis, A.T.B.; investigation, A.T.B., X.C.D., M.A.S.L., D.G.A., V.R.C.; resources, X.C.D., M.A.S.L., D.G.A., V.R.C.; data curation, A.T.B.; writing-original draft preparation, A.T.B.; writing-review and editing, A.T.B., X.C.D., M.A.S.L., D.G.A., V.R.C.; visualization, A.T.B., X.C.D., M.A.S.L., D.G.A., V.R.C.; funding acquisition, A.T.B., X.C.D., M.A.S.L., D.G.A., V.R.C. 
Funding: The work of Andrés Teira-Brión and the present research are included in the actions of the MILLET project "Old crops for new insights: agricultural systems of broomcorn and foxtail millet cultivation in Iberia", supported by a Marie Skłodowska-Curie Individual Fellowship H2020MSCA-IF-2020 (REA grant agreement ID: 101018935).

Acknowledgments: The radiocarbon dating of the Banco de España sample was funded by IncipitCSIC. The analysis of the Arcebispo Malvar excavation was carried out with the support of the Tanatorio Las Corrientes.

Conflicts of Interest: The authors declare no conflict of interest.

\section{References}

1. Prigogine, I. La nascita del tempo. 1988, Roma-Napoli: Theoria.

2. Ferreira Priegue, E.M. Galicia en el comercio marítimo medieval. 1988, A Coruna: Fundación "Pedro Barrié de la Maza".

3. Solano Fernández-Sordo, Á. Historia urbana en la Galicia medieval. Balance y perspectivas. Cuadernos de Estudios Gallegos, 2010. 57(123): p. 55-90.

4. Ferreira Priegue, E.M. El poblamiento urbano en la Galicia medieval. In El fenómeno urbano medieval entre el Cantábrico y el Duero: revisión historiográfica y propuestas de estudio, Solórzano Telechea, J.Á., Arizaga Bolumburu, B., Eds. 2002, Asociación de Jóvenes Historiadores de Cantabria: Santander. p. 367-420.

5. Sánchez Sánchez, X.M. Aproximación al concejo de la ciudad de Santiago de Compostela y su configuración en la Edad Media. Un poder urbano en el señorío eclesiástico. Espacio Tiempo y Forma. Serie III, Historia Medieval, 2019. 0(32): p. $413-448$.

6. Armas Castro, J. Transformaciones sociales y relaciones de poder en una Villa de Señorío. Pontevedra, siglos XIV-XV. Sémata, 1992. 4: p. 191-210.

7. Monsalvo Antón, J.M. Las ciudades europeas del medievo. 1997, Madrid: Síntesis.

8. Armas Castro, J. Pontevedra en los siglos XII a XV: configuración y desarrollo de una villa marinera en la Galicia Medieval. 1992, Fundación Pedro Barrié de la Maza conde de Fenosa: A Coruña.

9. López Carreira, A. A cidade medieval galega. 1999, Vigo: A Nosa Terra.

10. Armas Castro, J. El afianzamiento de la realidad urbana despues del año mil. In Historia de la ciudad de Santiago de Compostela, Portela Silva, E., Editor. 2003, Universidade de Santiago de Compostela: Santiago de Compostela. p. 81-126.

11. Schreg, R. Feeding the village-Reflections on the ecology and resilience of medieval rural economy. In Food in the Medieval Rural Environment, Klápště, J., Sommer, P., Eds. 2011, Brepols Publishers: Turnhout. p. 301-320.

12. Speleers, L.; van der Valk, J.M.A. Economic plants from medieval and post-medieval Brussels (Belgium), an overview of the archaeobotanical records. Quaternary International, 2017. 436: p. 96-109.

13. Andrade Cernadas, J.M.; López Carreira, A. O reino medieval de Galicia: crónica dunha mesmemoria. 2021, Vigo: Xerais.

14. D'Emilio, J. ed. Culture and Society in Medieval Galicia: A Cultural Crossroads at the Edge of Europe. The Medieval and Early Modern Iberian World. Vol. 58. 2015, Brill: Leiden / Boston.

15. Carballeira Debasa, A.M. Galicia y los gallegos en las fuentes árabes medievales. 2007, Santiago de Compostela: Consejo Superior de Investigaciones Científicas-CSIC, Instituto de Estudios Gallegos Padre Sarmiento.

16. Barros, C. La frontera medieval entre Galicia y Portugal. Medievalismo, 1994. 4(27-39).

17. Ferreira Priegue, E.M. Galicia en la Marisma de Castilla: la dinámica de los intercambios mercantiles. In El espacio urbano en la Europa medieval : Nájera. Encuentros Internacionales del Medievo, Arízaga Bolumburu, B., Solórzano Telechea, J.Á., Eds. 2005, Instituto de Estudios Riojanos: Logroño. p. 165-186.

18. Volokh, A. Property Rights and Contract Form in Medieval Europe. American Law and Economics Review, 2009. 11(2): p. 399-450.

19. Bolton, J.L. The Medieval English Economy 1150-1500. 1980, London: J.M. Dent \& Sons Ltd.

20. Pousa Diéguez, R. Del señorío medieval a la jurisdicción señorial en Galicia: transformaciones y cambios entre los siglos XIV y XVI. Medievalismo, 2018. 28: p. 175-202.

21. Isla Frez, A. La sociedad gallega en la Alta Edad Media. 1992, Madrid: Consejo Superior de Investigaciones Científicas.

22. Ferreira Priegue, E.M. Mercaderes gallegos de la Edad Media. Una aproximación pendiente. Sémata, 2000. 12: p. 19-34.

23. Portela Silva, E.; Pallares Méndez, M.C. La investigación histórica sobre la Edad Media en Galicia. In Galicia e a historiografia, González Beramendi, J., Editor. 1993, Tórculo Edicións: Santiago de Compostela.

24. Ibn al-`Awwām Kitāb al-Filāḥa. Libro de agricultura. Banqueri, Josef Antonio (Editor and translator, Madrid, 1802). 1988, Madrid: Ministerio de Agricultura.

25. Hernández Bermejo, J.E.; García Sánchez, E. Botánica económica y etnobotánica en al-Andalus (Península Ibérica siglos X-XV), un patrimonio desconocido de la humanidad. Arbor, 2000. 166(654): p. 311-331.

26. Abū l-Jayr Kitāb al-Filāḥa. Tratado de agricultura. Carabaza Bravo, Julia María (Editor and translator). 1991, Madrid: ICMA.

27. García Sánchez, E. La alimentación popular urbana en al-Andalus. Arqueología medieval, 1996. 4: p. $219-236$.

28. Portela Silva, E. La región del Obispado de Tuy en los siglos XII a XV: una sociedad en la expansión y en la crisis. 1976, Santiago de Compostela: El Eco Franciscano. 458.

29. Quirós Castillo, J.A.; Nicosia, C.; Polo-Díaz, A.; Ruiz del Árbol, M. Agrarian archaeology in northern Iberia: Geoarchaeology and early medieval land use. Quaternary International, 2014. 346: p. 56-68. 
30. Ballesteros Arias, P. La Arqueología Rural y la construcción de un paisaje agrario medieval: el caso de Galicia. In Por una arqueología agraria. Perspectivas de investigación sobre espacios de cultivo en las sociedades medievales hispánicas, Kirchner, H., Editor. 2010, Archaeopress: Oxford. p. 25-39.

31. Barceló, M.; Kirchner, H.; Navarro, C. El agua que no duerme. Fundamentos de la arqueología hidráulica andalusí. 1995, Granada: El Legado Andalusí.

32. Kirchner, H. ed. Por una arqueología agraria. Perspectivas de investigación sobre espacios de cultivo en las sociedades medievales hispánicas. 2010, Archaeopress: Oxford.

33. Ros, J.; Garrido Garcia, J.A.; Ruiz Alonso, M.; Gilotte, S. Bioarchaeological Results from the House 1 at Albalat (Romangordo, Extremadura, Spain): Agriculture, Livestock and Environment at the Margin of al-Andalus. Journal of Islamic Archaeology, 2018. 5(1): p. 71-102.

34. Quirós-Castillo, J.A.; Tereso, J.P.; Seabra, L. Social history of agriculture at medieval rural sites in the northern of the Iberia Peninsula: Aistra and Zornoztegi (Alava, Spain). Journal of Archaeological Science: Reports, 2020. 33: p. 102442.

35. Alonso, N.; Antolín, F.; Kirchner, H. Novelties and legacies in crops of the Islamic period in the northeast Iberian Peninsula: The archaeobotanical evidence in Madîna Balagî, Madîna Lârida, and Madîna Turțûša. Quaternary International, 2014. 346: p. 149-161.

36. Peña-Chocarro, L.; Pérez-Jordà, G.; Alonso, N.; Antolín, F.; Teira-Brión, A.; Tereso, J.P.; Montes Moya, E.M.; López Reyes, D. Roman and Medieval crops of the Iberian Peninsula: a first synthesis of seeds and fruits from archaeological sites. Quaternary International, 2019. 499(A): p. 49-66.

37. Peña-Chocarro, L.; Pérez-Jordà, G. Garden plants in medieval Iberia: the archaeobotanical evidence. Early Medieval Europe, 2019. 27(3): p. 374-393.

38. Treasure, E.R., The Frontier of Islam: An Archaeobotanical Study of Agriculture in the Iberian Peninsula (c. 700-1500 CE). 2020, Durham University. p. 304.

39. Watson, A.M. Agricultural Innovation in the Early Islamic World: The Diffusion of Crops and Farming Techniques, 700-1100. 1983, Cambridge: Cambridge University Press.

40. Decker, M. Plants and Progress: Rethinking the Islamic Agricultural Revolution. Journal of World History, 2009. 20 (2): p. 187-206.

41. Squatriti, P. Of Seeds, Seasons, and Seas: Andrew Watson's Medieval Agrarian Revolution Forty Years Later. The Journal of Economic History, 2014. 74(4): p. 1205-1220.

42. Watson, A.M. La conquista islámica y los nuevos cultivos de Al-Andalus. In Impactos exteriores sobre el mundo rural mediterráneo del Imperio Romano a nuestros días, Morilla Critz, J., Gómez-Pantoja Fernández-Salguero, J., Cressier, P., Eds. 1997, Ministerio de Agricultura: Madrid.

43. al-Bakrī Geografía de España (Kitāb al-masālik wa-l-mamālik). Vidal Beltrán, Eliseo (translator). 1982, Zaragoza: Anuba.

44. Teira Brión, A. Traditional millet cultivation in the Iberian Peninsula. Ethnoarchaeological reflections through the lens of social relations and economic concerns. In Millet and what else? The wider context of the adoption of millet cultivation in Europe, Kirleis, W., Dal Corso, M., Filipović, D., Eds. 2022, Sidestone Press: Leiden.

45. Toscano, S.; Scuderi, D.; Tribulato, A.; Romano, D. The Use of Brassicaceae by the Ancient Romans. In VI International Symposium on Brassicas and XVIII Crucifer Genetics Workshop 2013. International Society for Horticultural Science (ISHS), Leuven, Belgium.

46. Henderson, J. Columella's Living Hedge: The Roman Gardening Book. Journal of Roman Studies, 2002. 92: p. 110-133.

47. Bandini Mazzanti, M.; Bosi, G.; Guarnieri, C. The useful plants of the city of Ferrara (Late Medieval/Renaissance) based on archaeobotanical records from middens and historical/culinary/ethnobotanical documentation. In Plants and Culture: seeds of the cultural heritage of Europe, Morel, J.P., Mercuri, A.M., Eds. 2009, Edipuglia: Bari.

48. McAlvay, A.C.; Ragsdale, A.P.; Mabry, M.E.; Qi, X.; Bird, K.A.; Velasco, P.; An, H.; Pires, J.C.; Emshwiller, E. Brassica rapa Domestication: Untangling Wild and Feral Forms and Convergence of Crop Morphotypes. Molecular Biology and Evolution, 2021. 38(8): p. 3358-3372.

49. Ribera, A.; Bai, Y.; Wolters, A.-M.A.; van Treuren, R.; Kik, C. A review on the genetic resources, domestication and breeding history of spinach (Spinacia oleracea L.). Euphytica, 2020. 216(3): p. 48.

50. El Faïz, M. Ibn al-'Awwâm, Kitâb al-Filâha (Le livre de l'agriculture 12th century A.D.), ed. 1866), T.J.-J.C.-M.e. 2000, Arles: Actes Sud.

51. Hallavant, C.; Ruas, M.-P. The first archaeobotanical evidence of Spinacia oleracea L. (spinach) in late 12th-mid 13th century A.D. France. Vegetation History and Archaeobotany, 2014. 23(2): p. 153-165.

52. Peña-Chocarro, L.; Alkain, P.; Urteaga, M. Wild, managed and cultivated plants in northern Iberia: an archaeobotanical approach to Medieval plant exploitation in the Basque Country. European Journal of Post-Classical Archaeologies, 2014. 4: p. 131156.

53. Pollmann, B.; Jacomet, S. First evidence of Mespilus germanica L. (medlar) in Roman Switzerland. Vegetation History and Archaeobotany, 2012. 21(1): p. 61-68.

54. Teira Brión, A.; Currás Domínguez, A.; Portillo, M.; Albert, R.M.; Pérez Mato, M. La excavación arqueológica de los Grandes Almacenes El Pilar (Santiago de Compostela, Galicia, España): Un estudio arqueobotánico de silos de almacenaje medievales. Estudos do Quaternàrio, 2010. 6: p. 75-90.

55. Rodríguez Resino, Á. Sistemas subterráneos de almacenamiento en la Galicia medieval. Una primera tipología y consideraciones para su estudio. In Horrea, Barns and Silos. Storage and incomes in Early Medieval Europe, Vigil-Escalera Guirado, A., Bianchi, G., Quirós Castillo, J.A., Eds. 2013, Universidad del País Vasco/Euskal Herriko Unibertsitatea: Bilbao. 
56. Alonso Toucido, F.; Prieto Martínez, M.P.; Rodríguez Resino, Á. Cerámica en silos: contextos Medievais e Modernos na Rúa do Franco no 31, Santiago de Compostela. Gallaecia, 2013. 32: p. 215-248.

57. Jacomet, S. Archaeobotany. Analyses of Plant Remains from Waterlogged Archaeological Sites. In The Oxford Handbook of Wetland Archaeology, Menotti, F., O'Sullivan, A., Eds. 2013, Oxford University Press: Oxford. p. 497-514.

58. Moreno-Larrazabal, A.; Teira-Brión, A.; Sopelana-Salcedo, I.; Arranz-Otaegui, A.; Zapata, L. Ethnobotany of millet cultivation in the north of the Iberian Peninsula. Vegetation History and Archaeobotany, 2015. 24(4): p. 541-554.

59. López-Costas, O.; Müldner, G. Boom and bust at a medieval fishing port: dietary preferences of fishers and artisan families from Pontevedra (Galicia, NW Spain) during the Late Medieval and Early Modern Period. Archaeological and Anthropological Sciences, 2019. 11(8): p. 3717-3731.

60. Campbell, G.; Moffett, L.; Straker, V., Environmental Archaeology. A Guide to the Theory and Practice of Methods, from Sampling and Recovery to Post-excavation (second edition). 2011, English Heritage: Portsmouth.

61. Antolín Tutusaus, F.; Alonso Martínez, N. A Mourela (As Pontes, A Coruña): evidencias carpológicas de las prácticas de roza y del procesado y consumo de cereales en el monte gallego (siglos VII-XVII). In Círculo de engaños: Excavación del cromlech de A Mourela (As Pontes de García Rodríguez, A Coruña), Bonilla Rodríguez, A., Fábregas Valcarce, R., Eds. 2009, Editorial Andavira: Santiago de Compostela. p. 177-196.

62. Tente, C.; Baptista, H.; Tereso, J.P.; Cércio, M.; Veloso, J.L.; Oliveira, C.; Seabra, L.; Meira, C.; de Souza, G.; Cordero Ruíz, T.; Real, M.L. Senhora do Barrocal (Sátão) na viragem do milénio. Primeira abordagem. In Do Império ao Reino. Viseu e o território entre os séculos IV a XII, Tente, C., Editor. 2018, Câmara Municipal de Viseu: Viseu. p. 263-295.

63. Oliveira, C.; Jesus, A.; Tente, C.; Tereso, J.P. Estudo arqueobotânico do povoado alto-medieval de S. Gens: perspetivas sobre a exploração de recursos lenhosos e agrícolas. In Atas do II Congresso da Associação dos Arqueólogos Portugueses. 2017, Associação dos Arqueólogos Portugueses: Lisboa. p. 1463-1476.

64. Martín Seijo, M.; Antolín, F.; Alonso, N.; Fábregas Valcarce, R.; Bonilla Rodríguez, A. Prácticas agrícolas y gestión de los recursos forestales en el monte gallego entre los siglos VII y XVII AD. El caso de A Mourela (As Pontes, A Coruña). In Alterações Ambientais e Interacção Humana na Fachada Atlântica Occidental, Bettencourt, A.M.S., Alves, M.I.C., Monteiro-Rodrigues, S., Eds. 2010, Universidade do Minho: Braga. p. 133-148.

65. Teira Brión, A.; Martín Seijo, M.; Lombera Hermida, A.d.; Fábregas Valcarce, R.; Rodríguez Alvarez, X.P. Forest resource management during Roman and Medieval cave occupations in the Northwest of the Iberian Peninsula: Cova do Xato and Cova Eirós (Galicia, Spain). Sagvntum: Papeles del Laboratorio de Arqueología de Valencia, 2012. 13: p. 159-166.

66. López Sabatel, J.A. Uso y transformación en espacio agrario del monte y del estrato arbóreo en la Ribeira Sacra durante los siglos XIV y XV. Cuadernos de Estudios Gallegos, 2009. 122: p. 213-233.

67. Ríos Rodríguez, M.L. Soutos bravos y soutos mansos: el castaño en Galicia (siglos XII-XIV). In El medio natural en la España medieval: actas del I Congreso sobre ecohistoria e historia medieval, Clemente Ramos, J., Editor. 2001, Universidad de Extremadura Servicio de Publicaciones: Cáceres. p. 475-488.

68. López Alsina, F. La ciudad de Santiago de Compostela en la Alta Edad Media. 1988, Santiago de Compostela: Ayuntamiento de Santiago de Compostela.

69. González Vázquez, M. El agua y sus sistemas de suministro en la Compostela Medieval. In Actas del Segundo Congreso Nacional de Historia de la construcción, Bores, F., Editor. 1998, Universidade da Coruña: A Coruña.

70. Teira Brión, A. Cultivos e froiteiras na Idade Media en Galicia. O conxunto carpolóxico da escavación do Banco de España (Santiago de Compostela). Gallaecia, 2015. 34: p. 209-226.

71. Martín-Seijo, M.; Sartal Lorenzo, M.; Kaal, J.; Teira-Brión, A. A Multi-Disciplinary Study of Woodcrafts and Plant Remains that Reveals the History of Pontevedra's Harbour (Northwest Iberia) Between the 13th and 19th Centuries AD. Environmental Archaeology, 2021. 26(2): p. 192-208.

72. Karg, S. Fruit and nut choices in the medieval and early Modern Baltic countries. In Des fruits d'ici et d'ailleurs. Regards sur l'histoire de quelques fruits consommés en Europe, Ruas, M.-P., Editor. 2016, Omniscience: Montreuil.

73. Barbeito Pose, V.J.; Rúa Carril, V. Evidencias arqueolóxicas da cerca e dos suburbios medievais de Villa Patrono (Padrón, A Coruña). Gallaecia, 2008. 27: p. 241-271.

74. Bronk Ramsey, C. Bayesian Analysis of Radiocarbon Dates. Radiocarbon, 2009. 51(3): p. 337-360.

75. Reimer, P.J.; Austin, W.E.N.; Bard, E.; Bayliss, A.; Blackwell, P.G.; Bronk Ramsey, C.; Butzin, M.; Cheng, H.; Edwards, R.L.; Friedrich, M.; Grootes, P.M.; Guilderson, T.P.; Hajdas, I.; Heaton, T.J.; Hogg, A.G.; Hughen, K.A.; Kromer, B.; Manning, S.W.; Muscheler, R.; Palmer, J.G.; Pearson, C.; van der Plicht, J.; Reimer, R.W.; Richards, D.A.; Scott, E.M.; Southon, J.R.; Turney, C.S.M.; Wacker, L.; Adolphi, F.; Büntgen, U.; Capano, M.; Fahrni, S.M.; Fogtmann-Schulz, A.; Friedrich, R.; Köhler, P.; Kudsk, S.; Miyake, F.; Olsen, J.; Reinig, F.; Sakamoto, M.; Sookdeo, A.; Talamo, S. The IntCal20 Northern Hemisphere Radiocarbon Age Calibration Curve (0-55 cal kBP). Radiocarbon, 2020. 62(4): p. 725-757.

76. Del Río Canedo, V.; Ferreiro Diz, O.; Alonso Toucido, F. Ajuar doméstico en las mesas compostelanas de época medieval: madera y cerámica como caso de estudio. In Estudo de Arqueoloxía, Prehistoria e Historia Antiga: achegas dos novos investigadores, Cordeiro Macenlle, R., Vázquez Martínez, A., Eds. 2016, Andavira Editora, S.L.: Santiago de Compostela. p. $425-438$.

77. Alonso Toucido, F.; Prieto Martínez, M.P. Periodizando la cerámica de la Edad Media en Galicia: el caso de O Bordel (Padrón). In Investigaciones Arqueológicas en el valle del Duero: Del Paleolítico a la Edad Media, 6, Hernández Gutiérrez, N., Larrazabal Galarza, J., Portero Hernández, R., Eds. 2018, Glyphos Publicaciones: Valladolid. p. 574-592.

78. Martín Seijo, M., A xestión do bosque e do monte dende a Idade do Ferro á época romana no noroeste da península Ibérica: consumo de combustibles e produción de manufacturas en madeira. 2013, Universidade de Santiago de Compostela: Santiago de Compostela. 
79. Antolín, F.; Steiner, B.L.; Jacomet, S. The bigger the better? On sample volume and the representativeness of archaeobotanical data in waterlogged deposits. Journal of Archaeological Science: Reports, 2017. 12(Supplement C): p. 323-333.

80. Steiner, B.L.; Antolín, F.; Jacomet, S. Testing of the consistency of the sieving (wash-over) process of waterlogged sediments by multiple operators. Journal of Archaeological Science: Reports, 2015. 2(0): p. 310-320.

81. Anderberg, A.-L. Atlas of seeds and small fruits of Northwest-European plant species with morphological descriptions. Stockholm.: Part, 1994. 4.

82. Bojnanský, V.; Fargašová, A. Atlas of seeds and fruits of Central and East-European flora: the Carpathian Mountains region. 2007, Dordrecht: Springer Science \& Business Media.

83. Cappers, R.T.J.; Bekker, R.M.; Jans, J.E.A. Digitale Zadenatlas van Nederland/Digital seed atlas of the Netherlands. Vol. 4. 2012, Groningen: Barkhuis publishing \& Groningen University Library.

84. Neef, R.; Cappers, R.T.J.; Bekker, R.M. Digital Atlas of Economic Plants in Archaeology. 2012, Groningen: Barkhuis \& Groningen University Library. 760.

85. Sabato, D.; Peña-Chocarro, L. Maris Nostri Novus Atlas: Seeds and fruits from the Mediterranean Basin. 2021, Aranjuez: Doce Calles.

86. Schöch, W.H.; Pawlik, B.; Schweingruber, F.H. Botanische Makroreste. 1988, Bern: Haupt. 